Poznań

\title{
Definiowanie demokracji w doktrynie Kościoła katolickiego
}

\section{K} ościół katolicki po wielu stuleciach ścisłego związku z systemem feudalnym stanął w obliczu konieczności przystosowania się do liberalnej ideologii mieszczańskiej, a następnie musiał sprecyzować swoje stanowisko w kwestii rosnących w siłę ruchów robotniczych oraz tworzonego przez proletariat nowego zarówno politycznego, jak i społecznego porządku. Od początku swego istnienia do dnia dzisiejszego Kościół czuł się zagrożony przez nowopowstałe prądy i kierunki filozoficzne, społeczne oraz naukowe, które nie były zgodne z jego nauczaniem (katolickim światopoglądem). Jak stwierdza Józef Keller, rozwój katolicyzmu realizował się wprawdzie wskutek wchłaniania obcych nurtów myślowych oraz kierunków społecznych, natomiast akceptowanie oraz przyjmowanie ich przez Kościół dokonywało się zawsze pod presją warunków historycznych. Watykan uznawał „,nowości” dopiero wówczas, kiedy stawały się na tyle znaczące, iż potępienie ich, czy też ignorowanie wyniosłym milczeniem byłoby co najmniej nierozsądne ${ }^{1}$.

J. Keller podaje tu jako przykład przez prawie dwa tysiące lat potępianą, uznawaną za sprzeczną z wiarą chrześcijańską - zasadę wolności religijnej, a podczas Vaticanum Secundum nazwaną jednym z elementarnych pierwiastków doktryny katolickiej². Jak piszą Konstanty Grzybowski oraz Barbara Sobolewska, stosunek Kościoła katolickiego do wszystkich innych religii, aż do pontyfikatu Piusa XII polegał na ,nieutrzymywaniu z nimi jakichkolwiek stosunków" ". Dopiero Jan XIII zapoczątkował politykę, której celem jest pojednanie wszystkich religii świata, a nawet dążenie ku konfederacji wszystkich, bądź wybranych Kościołów chrześcijań-

J. Keller, Katolicyzm jako religia i ideologia, Warszawa 1979, s. 218.

Ibidem.

3 K. Grzybowski, B. Sobolewska, Doktryna polityczna i społeczna papiestwa (1789-1968), Warszawa 1971, s. 171. 
skich. Na przestrzeni ostatnich stu lat można wyodrębnić trzy etapy formowania się relacji Kościół-świat. Pierwszy z nich trwał od początków instytucjonalizacji Kościoła do pontyfikatu Leona XIII. Był to okres typowo defensywny i wyrażał się w krytykowaniu, potępianiu bądź też zbywaniu milczeniem wszystkich tendencji, prądów oraz kierunków naukowych, filozoficznych i społecznych - uznanych przez władze Kościoła za niebezpieczne dla katolicyzmu. Etap drugi natomiast (od Leona XIII do Piusa XII) to czas redagowania (kształtowania) kompromisowego stanowiska względem liberalizmu na płaszczyznach: społecznej, politycznej oraz gospodarczej. Jak pisze J. Keller, w tym okresie Kościół „wypracował własny model organizowania świata w sferze doktrynalnej i polityczno-społecznej"4. Doszło wówczas do umocnienia sojuszu pomiędzy Kościołem a burżuazja, którego celem było zjednoczenie sił w walce z socjalizmem i komunizmem.

Warto w tym miejscu wspomnieć o tym, jak postrzegał kwestię wolności Leon XIII. Papież ten, odmiennie niż jego poprzednicy (zaczynając od stanowiska Piusa VI wobec pojęcia wolności opinii w Deklaracji Praw Człowieka i Obywatela z 1789 roku) przyjął, że wolność opinii istnieje jako zasada, jednakże z zastrzeżeniem, iż nie jest to wolność nieograniczona. Jak piszą K. Grzybowski oraz B. Sobolewska, warunek ten wydaje się bardzo ważny, ponieważ według Leona XIII wolność opinii istnieje jako prawo obywatelskie i jest za takie uważane tylko wówczas, jeśli jest w pewnych określonych przez Kościół dziedzinach ograniczone ${ }^{5}$. Wolność myślenia jako zasada była przez władze Kościoła długo odrzucana. Potępił ją na tajnym konsystorzu (29 marca 1790 roku) Pius VI. Wydarzenie to uznaje się za pierwsze potępienie haseł Wielkiej Rewolucji Francuskiej. Negatywnie oceniono m.in. artykuł głoszący, że „istnieje wolność myślenia, także o religii, jak się komu podoba, oraz wolność bezkarnego głoszenia swoich myśli” ${ }^{\circ}$.

W wypowiedziach Leona XIII uległo zmianie ujęcie tego zagadnienia pod względem konstrukcji. Papież skrytykował bowiem nie samą zasadę wolności myślenia, ale jej nieograniczoność. W obliczu rozkwitu burżuazyjnej demokracji oraz rosnącego w siłę ruchu robotniczego, Leon XIII

4 J. Keller, Katolicyzm jako religia i ideologia, Warszawa 1979, s. 219.

5 K. Grzybowski, B. Sobolewska, Doktryna polityczna i spoleczna papiestwa (1789-1968), Warszawa 1971, s. 66-67.

${ }^{6}$ Cyt. za K. Grzybowski, B. Sobolewska, Doktryna polityczna i spoleczna papiestwa (1789-1968), Warszawa 1971, s. 66-67. 
nie mógł w ślad za swoimi poprzednikami ograniczyć się jedynie do negacji tej zasady. Słusznie stwierdzają K. Grzybowski i B. Sobolewska, że stanowisko tegoż zwierzchnika Kościoła w kwestii wolności opinii można określić jako „wyłom w XIX-wiecznej doktrynie Watykanu”’ . Jednakże biorąc pod uwagę zastrzeżenie warunkujące mówiące o tym, iż ograniczenia i wyjątki od wyżej wspomnianej zasady ustala Kościół, „kompromis Leona XIII na gruncie jego uwspółcześnionej w tym zakresie teorii, nie będzie nim w tym samym stopniu w praktyce" $"$.

Zainicjowana przez Leona XIII próba uznania wolności jako zasady szła w parze z akceptacją (w określonym stopniu) burżuazyjnej demokracji. Ramami politycznymi, w jakich miała funkcjonować katolicka część świata powinno być państwo burżuazyjne - demokratyczne bo z wybieralnym parlamentem, a niedemokratyczne, ponieważ z funkcjonującym niepowszechnym i nierównym prawem wyborczym. Formuła ta jest daleka od współczesnej definicji demokracji. Należące do kręgu europejskiej kultury politycznej demokratyczne państwo odwołuje się do powszechnie uznawanych zasad, wartości oraz norm stosowanych oraz rozwijanych w procesach cywilizacyjnych przemian. Odnosząc się do wypowiedzi Konstantego Adama Wojtaszczyka warto w tym miejscu wspomnieć, iż współczesne demokratyczne państwo konstytucyjne jest (powinno być) państwem prawa, realizującym (w szczególności) reguły: suwerenności narodu, pluralizmu politycznego oraz podziału władzy. Zdaniem K. A. Wojtaszczyka ogromny wpływ na stabilność demokratycznego państwa w europejskim kręgu kulturowym mają zasady zwyczajowe tj. racjonalność i tolerancja? .

Racjonalność, jak pisze wyżej wspomniany autor, oznacza wyodrębnienie celów od środków. Takie podejście stwarza możliwość wypracowania decyzji, których realizowanie zaspokaja potrzeby zarówno jednostkowe, jak i zbiorowe. W systemie demokratycznym, tolerancja oznacza przede wszystkim uznawanie, poszanowanie i respektowanie prawa człowieka do odmiennych poglądów, gustów, sposobów życia, postaw, obyczajów, zwyczajów preferencji, z pominięciem idei antyhumanistycznych, zbrodniczych, terrorystycznych (państwo ma chronić także te osoby, które sprzeciwiają się demokracji - jeżeli formy zachowania nie naruszają obo-

Ibidem, s. 67-68.

8 K. A. Wojtaszczyk, Kompendium wiedzy o państwie współczesnym, Warszawa 2000, s. 59.

9 Ibidem. 
wiązujących w danym kraju norm prawnych). Demokratyczne państwo utrwala wartości takie jak wolność, równość, sprawiedliwość, porządek. Wolność jest wartością nadrzędną. Stanowi elementarne i niezbywalne prawo jednostki. Równość oznacza przede wszystkim równość wobec obowiązującego systemu prawa. Natomiast porządek (jako wartość) jest zasadą postępowania zarówno indywidualnego, jak i zbiorowego, akceptującego i przyjmującego reguły obowiązującego w państwie demokratycznym ładu ${ }^{10}$.

Państwo liberalnej demokracji posługuje się pojęciem dobra na określenie tego, co w powszechnie panującym przekonaniu stanowi źródło satysfakcji i co (obok wiedzy) wyznacza nasze zachowania. W jego obrębie stwierdza się istnienie wartości kulturowo uwarunkowanych i nie uwarunkowanych; subiektywnych i intersubiektywnych; społecznie obojętnych, a także społecznie chronionych. Do wartości społecznie chronionych należy zaliczyć wartości moralne, a pośród nich wartości altruistyczne (moralne w węższym sensie) oraz wartości obyczajowe (ceremonialne). Oswajamy się z nimi od wczesnego dzieciństwa. Wdrażanie ich odbywa się początkowo za pomocą systemu kar i nagród, a następnie poprzez indoktrynację tych wartości ${ }^{11}$.

Jak pisze Barbara Stanosz, kodeks molarny liberała jest ściśle związany z pojęciem wolności: ,akceptacja zasady wolności jednostki sprawia, że zakres tradycyjnie uznawanych obligacji moralnych poddany zostaje rewizji, w wyniku której obligacje o charakterze obyczajowym kolidujące z zasadą wolności zostają złagodzone lub uchylone; zachowany zostaje natomiast (w pewnych punktach nawet wzmocniony) tradycyjny system wartości moralnych w węższym sensie, zwanych altruistycznymi, tj. tych, które mają bezpośrednio na celu satysfakcję innych osób [...]"12. Tak więc pewne wartości kulturowe np. zachowanie „przyzwoitości” w mowie, ubiorze, respektowanie tabu z nimi związanych, a także wartości religijne - wyznaczające schemat życia seksualnego, osobistego. rodzinnego przestają być istotne. Natomiast spoglądając w tym kontekście na katolicyzm można stwierdzić, iż wartości moralne bardzo trudno jest oddzielić od

10 Ibidem, s. 59-61.

11 B. Stanosz, Konflikt wartości liberalnych i katolickich, w: Materiały i rozprawy do teorii dziejów i współczesności liberalizmu, Sympozjum historyczne: „Liberalizm i katolicyzm dzisiaj" (Lublin 10-12 XI 1992), opr. R. Benedykciuk, T. Markiewicz, Warszawa 1994, s. 11.

12 Ibidem, s. 14. 
wartości stricte religijnych - zarówno pod względem motywacji, jak i zawartości merytorycznej. Właściwie tworzą one całość ${ }^{13}$.

Warto powtórzyć za B. Stanosz, że wartości moralne, na których opiera się nauczanie Kościoła katolickiego „opisuje się przy tym w sposób metaforyczny, co utrudnia ich identyfikację. Wątpliwa jest też wewnętrzna koherencja katolickiego systemu wartości moralnych"14. Za fundamentalną wartość altruistyczną (obecną w katolicyzmie) uznaje się chrystusowe polecenie „miłowania bliźniego swego jak siebie samego”. Zdaniem Ryszarda Paradowskiego, to przykazanie, a w szczególności jego drugi człon - ,jak siebie samego" stało się przyczyną kulturowej rewolucji (w rozumieniu prawa). Zgodnie z wypowiedzią R. Paradowskiego, zasada „miłości bliźniego jak siebie samego" wnosi do systemu prawa regułę wzajemnych wymagań, natomiast prawo tradycyjne opierało się tylko na normach jednostronnych. Na tym przykazaniu miało się oprzeć Nowe Przymierze ${ }^{15}$.

Jak słusznie stwierdza R. Paradowski, założenia Nowego Przymierza udało się zrealizować jedynie częściowo. Warto powtórzyć za tym autorem, iż propagowanie miłości bezgranicznej nie było dla Jezusa wcale proste, bowiem trudno było odwieść ludzi od wypełniania starotestamentowego prawa „oko za oko”. Wobec tego, Jezus polecił „nadstawienie drugiego policzka”. Okoliczności te, nie mogły służyć „skonstruowaniu Przymierza prawdziwie nowego"16. W myśl koncepcji R. Paradowskiego „rewolucyjna w stosunku do starej moralności zasada pokory zinstytucjonalizowana została w późnym antyku, a następnie w średniowieczu w postaci despotycznego państwa i różnych form społecznego poddaństwa, odwołujących się do wymogu chrześcijańskiej pokory”. Miłości bliźniego został nadany w nowej redakcji status normy drugorzędnej, uzupełniającej, „nakazujące miłowanie 'bliźnich' w zakresie i formach, narzuconych przez najwyższy autorytet"17.

Należy w tym miejscu powtórzyć za B. Stanosz, że katolicki system wartości w wielu kwestiach jest sprzeczny z liberalnym ponieważ „dra-

13 Ibidem, s. 14-16.

14 Ibidem, s. 15.

15 R. Paradowski, Władza i prawo. Studium z hermeneutyki politycznej, w: Środkowoeuropejskie studia polityczne, t. 1, red. R. Paradowski, Wydawnictwo Naukowe INPiD UAM, Poznań 2004, s. 12.

16 Ibidem.

17 Ibidem, s. 12-13. 
stycznie ogranicza on wolność człowieka w sprawach, w których liberalizm przyznaje człowiekowi pełną swobodę wyboru. Konsekwencją psychospołeczną realizowania takiego systemu wartości (pod warunkiem osiaggnięcia w tym względzie odpowiedniej skuteczności) byłoby, jak pisze B. Stanosz, zamknięte, zniewolone tradycją społeczeństwo wiernych poddanych, bezwolne i pokorne wobec oficjalnych autorytetów oraz odizolowanych od innych kultur. Taki stan rzeczy służy budowaniu państwa autokratycznego, a nawet totalitarnego ${ }^{18}$. Zdaniem R. Paradowskiego, „Do ostatecznej degradacji przeznaczonego do roli najwyższej metafizycznej zasady przykazania miłości bliźniego i zastąpienia go przez miłość bezwarunkową jako archetyp przyszłych despotii, autorytaryzmów i totalitaryzmów przyczynił się w szczególności Paweł z Tar$\mathrm{su}^{\prime \prime}$.

W katolicyzmie, podobnie jak w innych wielkich, rozwiniętych religiach wyodrębnić można trzy zasadnicze elementy strukturalne: doktrynę, kult oraz organizację. Doktryna Kościoła katolickiego wywodzi się przede wszystkim z Pisma Świętego, które określa się mianem „objawionej woli bożej". Mimo, iż pewnym słowom biblijnym przypisuje się stały i niepodważalny sens, to jednak interpretacja treści Pisma Świętego w dużym stopniu jest uzależniona od zmieniających się realiów (historycznych uwarunkowań). Właśnie na tym gruncie powstała tradycja - jako drugie źródło doktryny katolickiej. Zawarte w Piśmie Świętym twierdzenia, które sąjasne, czytelne i zrozumiałe lub też zostały uznane mocą soborów powszechnych lub papieży za nienaruszalne i obowiązujące wszystkich wiernych w sposób niezmienny i bezwarunkowy nazwano dogmatami. Obok dogmatów istnieją także inne twierdzenia, a mianowicie: „bliskie wiary” (fidei proxima); ,pewne” (certa); oraz „ogólnie uznawane” (communia). Mimo, że ich teologiczna kwalifikacja jest różna, wierni muszą je traktować jak ,prawdy wiary”. Poniżej „prawd wiary” znajdują się w doktrynie Kościoła orzeczenia papieży, kongregacji rzymskich oraz biskupów, które nie wkraczają bezpośrednio w sferę wiary, lecz dotyczą

18 B. Stanosz, Konflikt wartości liberalnych i katolickich, w: Materiaty i rozprawy do teorii dziejów i współczesności liberalizmu, Sympozjum historyczne: „Liberalizm i katolicyzm dzisiaj" (Lublin 10-12 XI 1992), opr. R. Benedykciuk, T. Markiewicz, Warszawa 1994, s. 15-16.

19 R. Paradowski, Władza i prawo. Studium z hermeneutyki politycznej, w: Środkowoeuropejskie studia polityczne, t. 1, red. R. Paradowski, Wydawnictwo Naukowe INPiD UAM, Poznań 2004, s. 13. 
poglądów władz Kościoła na istniejącą w danym czasie sytuację na świecie ${ }^{20}$.

Kult - kolejny strukturalny składnik religii, jest w katolicyzmie ujęty w sztywne formy. Od tych form zależy zarówno prawowierność wykonywanych czynności, jak również ich skuteczność. Na początku, poprzez chrzest sformalizowano kwestię przyjęcia w poczet członków Kościoła. Następnie wprowadzono podział wiernych na dwie oddzielne grupy: duchownych i świeckich. O ważności wykonywanych czynności kultowych decyduje nie charyzmat personalny (osobiste walory duchownego), ale charyzmat urzędowy (przynależność do stanu duchownego). W kwestii organizacji (trzeci element strukturalny) katolicyzm w stosunku do innych wielkich religii odznacza się maksymalnym stopniem sformalizowania. Jednostka staje się członkiem organizacji wyznaniowej poprzez chrzest - zazwyczaj z woli opiekunów, ponieważ chrztu udziela się niemal wyłącznie w niemowlęctwie. Chrzest, który wywiera „niezmazalne piętno” na duszy człowieka ma skutek nieodwracalny. Ochrzczona osoba pozostaje członkiem Kościoła do końca życia ${ }^{21}$.

Instytucja Kościoła zbudowana jest hierarchicznie. Zadanie nauczania oraz rządzenie przypisane jest tylko osobom należącym do stanu duchownego. Osoby świeckie, zgodnie z regułami katolicyzmu, stanowią „,masę wierzących, kierowanych i nauczanych", a obecna na kartach dziejów Kościoła walka o dopuszczenie świeckich do zarządu Kościołem kończyła się przeważnie fiaskiem. W praktyce, realizowanie w Kościele władzy nie zawsze odnosiło takie same skutki. Katolicyzm jest religią opartą na prawie, a rządzący Kościołem byli zmuszeni przy stosowaniu norm prawnych do uwzględnienia aktualnie panującej na świecie oraz w obrębie Kościoła sytuacji. Jak stwierdza J. Keller, „Masy ludzi wierzących bowiem, z pozoru bierne i bezczynne, stwarzają atmosferę, z jaką hierarchia kościelna musi się liczyć. A jeszcze więcej musi się liczyć z poglądami głoszonymi przez aktywne jednostki i ugrupowania wewnątrz Kościoła”.

20 Warto podkreślić, że w tej sferze „prawdy wiary” występują razem z praktycznymi wskazówkami dotyczącymi zachowania się wiernych w nieustannie zmieniających się warunkach życia społecznego, ekonomicznego i politycznego. Celem tworzenia, utrwalania i wreszcie przestrzegania doktryny nie jest zapobieganie niebezpieczeństwu wejścia na drogę herezji bądź też schizmy, ale zachowanie posłuszeństwa wobec kościelnej hierarchii (J. Keller, Katolicyzm jako religia i ideologia, Warszawa 1979, s. 8-9).

21 Ibidem, s. 9-10. 
Warto także powtórzyć za J. Kellerem, iż rozwój doktryny kultu katolickiego jest ściśle związany z historią instytucji Kościoła ${ }^{22}$. Dlatego też, wątek historyczny nie mógł zostać tu pominięty.

Zdaniem O. Jana Mazura, Kościół mimo, iż stanowi instytucję „demokratyczną" jest jednocześnie gwarantem demokracji. Autor ten pisze, że w przeciwieństwie do totalitaryzmu, demokracja uznaje obecność takich sfer ludzkiego życia, które nie mogą prawomocnie podlegać żadnej kontroli politycznej, co jest rezultatem, ,istotnego wpływu religii chrześcijańskiej”23. Zgodnie z wypowiedzią O. J. Mazura: „Ponad władzą państwową istnieje władza Boga, czego nie uznaje i nie respektuje państwo totalitarne. Państwo demokratyczne zaś umożliwia, a nawet sprzyja rozwojowi Kościoła, gdyż jest on jednym z elementów urzeczywistniających jego prawdziwy rozwój" ${ }^{24}$. Z kolei Eugeniusz Zieliński uważa, że współczesne państwo liberalno-demokratyczne oparte jest na „wolności jednostek, stanowionych prawach, zabezpieczonych swobodach obywatelskich oraz określanych granicach ingerencji władzy publicznej w sferę życia prywatnego" 25 . Nasuwa się stwierdzenie, iż państwo, o którym pisze O. J. Mazur to raczej autorytarne państwo wyznaniowe, bowiem władza Boga, która może być przez władze kościelne rozmaicie rozumiana i interpretowana stoi powyżej władzy państwowej.

Podczas II Soboru Powszechnego (Vaticanum Secundum) Kościół na kartach oficjalnego dokumentu stwierdził, iż nowoczesne, świeckie i religijne pluralistyczne państwo jest prawomocną formą społeczną. Należy jednakże powtórzyć za B. Sobolewską oraz K. Grzybowskim, iż w dokumentach soborowych brakuje stanowiska w kwestii laicyzmu państwa. Problem ten poruszono tylko pośrednio. Stwierdzając, że współczesne społeczeństwo jest pluralistyczne ojcowie soborowi częściowo (pośrednio) uznali laickość państwa. Jak pisze Paweł Borecki, zmiany doktrynalne

22 Instytucja Kościoła została uznana za jeden z najważniejszych pierwiastków doktryny już u schyłku II wieku. W czasie, gdy wiara chrześcijan w eschatologiczne królestwo boże została przekształcona w wiarę w faktycznie istniejący Kościół jako instytucję zbawiająca, kiedy w chrześcijańskich osadach zaczęto powtarzać wyznanie: „wierzę w święty Kościół powszechny...” - instytucja Kościoła występuje jako jeden z fundamentalnych elementów doktryny katolickiej. W religii katolickiej elementy: doktrynalny, organizacyjny oraz kultowy są związane nierozerwalnie (J. Keller, Katolicyzm jako religia i ideologia, Warszawa 1979, s. 10-11).

23 O. J. Mazur, Politologia chrześcijańska, Częstochowa 2001, s. 84-85.

24 Ibidem.

25 E. Zieliński, Nauka o państwie i polityce, Warszawa 1999, s. 106. 
w tej kwestii pozwalały „mówić wręcz o końcu ery konstantyńskiej. Sobór wypowiadając się w sprawie odniesień Kościoła i państwa, nawiązywał do niektórych wcześniejszych wypowiedzi Magisterium, wyraźnie odrzucając ideał państwa katolickiego, nie zdefiniował jednoznacznie preferowanego modelu wzajemnych relacji wymienionych podmiotów, w szczególności nie zaakceptował wprost systemu rozdziału Kościoła i państwa" ${ }^{, 26}$. Zdaniem P. Boreckiego, dokumenty soborowe dotyczące tej kwestii cechuje wysoki stopień ogólności, a także terminologia o „niewypracowanej wykładni w nauce prawa wyznaniowego i konstytucyjnego"27.

Znaczenie doktrynalne Vaticanum Secundum jest ogromne. Kościół zaakceptował w końcu autonomię rzeczywistości doczesnej. W takiej sytuacji konieczne było sformułowanie nowych poglądów dotyczących państwa - w dokumentach soborowych nazwanego wspólnotą polityczną. W konstytucji Gaudium et spes czytamy: „Kościół, który z racji swego zadania i kompetencji nie utożsamia się ze wspólnotą polityczną, ani nie wiąże się z żadnym systemem politycznym, jest zarazem znakiem i zabezpieczeniem transcendentnego charakteru osoby ludzkiej. Wspólnota polityczna i Kościół są w swoich dziedzinach od siebie niezależne i autonomiczne"28. Jak wynika z wyżej cytowanej wypowiedzi, Kościół uznał odrębność państwa zarówno w sferze kompetencyjnej, jak i instytytucjonalnej, co wynikało z uznania przez Kościół apolitycznego charakteru jego pierwotnej misji. Sobór II sprzeciwił się także wszelakim próbom politycznej instrumentalizacji Kościoła. Zrezygnowano z „,ideału państwa integralnie katolickiego" natomiast nie zaakceptowano rozdziału Kościoła i państwa. Jak podkreśla P. Borecki, ojcowie soborowi „nie wykluczyli regulacji położenia prawnego Kościoła na podstawie umowy międzynarodowej, zarazem świadomie nie uznali modelu separacji za błędny i szkodliwy" "29. Za fundamentalną zasadę w kształtowaniu relacji pomiędzy Kościołem a państwem uznano wolność Kościoła.

26 K. Grzybowski, B. Sobolewska, Doktryna polityczna i społeczna papiestwa (1789-1968), Warszawa 1971, s. 184.

27 P. Borecki, Koncepcja relacji Kościoła i państwa w nauczaniu społecznym Jana Pawta II, „Przegląd Religioznawczy” 2005, nr 1, s. 37-38.

${ }^{28}$ Konstytucja duszpasterska o Kościele $w$ świecie współczesnym (Gaudium et spes), w: Dokumenty, w: K. Grzybowski, B. Sobolewska, Doktryna polityczna i spoleczna papiestwa (1789-1968), Warszawa 1971, s. 488-489.

29 P. Borecki, Koncepcja relacji Kościoła i państwa w nauczaniu społecznym Jana Pawta II, „Przegląd Religioznawczy” 2005, nr 1, s. 38. 
Zgodnie z treścią Gaudium et spes należy potępić „wszelkie formy ustroju politycznego, panujące w niektórych krajach, które krępują swobodę obywatelską lub religijną, mnożą ofiary namiętności i przestępstw politycznych, a sprawowanie rządów przestawiają ze służby dobru wspólnemu na dogadzanie jakiemuś stronnictwu lub na korzyść władzy państwowej”30. Kościół sprzeciwił się zatem istnieniu autorytarnych i totalitarnych reżimów. Dalej stwierdzono, że nic mocnej ,nie sprzyja odnowieniu życia politycznego na prawdziwie ludzkich zasadach, jak popieranie głębokiego poczucia sprawiedliwości i życzliwości oraz służby dobru wspólnemu, a także umacnianie podstawowych poglądów na prawdziwą naturę wspólnoty politycznej, jej cel, i na praworządność oraz zakres władzy państwowej"31.

Zgodnie z opinią B. Sobolewskiej i K. Grzybowskiego, treść Gaudium et spes, pomimo oświadczenia, zgodnie z którym Kościół nie utożsamia się z żadnym systemem politycznym, stanowi wyraz poparcia dla ustroju demokratycznego. Słowo demokracja w konstytucji nie pada, natomiast znalazło się ono w indeksie wydania urzędowego, ze wskazaniem na sformułowania dotyczące ustroju politycznego. Napisano tam, iż demokracja „jest pochwalona” (laudatur). Stwierdzono, iż jest to system, w którym „forma ustroju i wybór władz pozostawione są wolnej woli obywateli”32. Warto powtórzyć za K. Grzybowskim i B. Sobolewską, iż w wypowiedzi tej tkwi pośrednie uznanie zasady suwerenności ludu i to nie tylko jako czynnika, który prawomocnie urządza ustrój polityczny (władza ustrojodawcza ludu), ale również jako czynnika roszczącego sobie prawo do powoływania władz państwowych ${ }^{33}$. Zdaniem tych autorów, twierdzenie mówiące o pochodzeniu władzy od Boga jest w Gaudium et spes wyraźnie

30 Konstytucja duszpasterska o Kościele w świecie współczesnym (Gaudium et spes), w: Dokumenty, w: K. Grzybowski, B. Sobolewska, Doktryna polityczna i społeczna papiestwa (1789-1968), Warszawa 1971, s. 488-486.

31 Ibidem.

32 Cyt. za K. Grzybowski, B. Sobolewska, Doktryna polityczna i społeczna papiestwa (1789-1968), Warszawa 1971, s. 188.

33 W myśl stanowiska prezentowanego przez K. Grzybowskiego i B. Sobolewska, pierwsza z przedstawionych wyżej zasad, czyli ustrojodawcza władza ludu stanowi zwrócenie się ku tezie demokratycznej szkoły jezuickiej z przełomu XVI i XVII wieku, w myśl której tylko samo istnienie wspólnoty politycznej pochodzi od Boga. Do ludu natomiast należy określenie sposobu, w jaki chce on być rządzony - ustanowienie ustroju państwa. Druga zasada, a mianowicie prawo do powoływania organów władzy sięga dalej niż jezuici doby Renesansu, którzy uważali, że źródłem każdego ustroju politycznego jest zawsze wola ludu. Lud zaś może przelać pełnię władzy na inny podmiot, przykładowo monarchę czy arystokrację (ibidem). 
osłabione, bowiem skoro „opiera się na naturze ludzkiej” przez Boga stworzonej, to nie może jednocześnie bezpośrednio od Boga pochodzić. Widoczne jest więc w konstytucji „odrzucenie zasady legitymizmu - prawa do władzy nie wywodzącego się z woli obywateli" ${ }^{34}$. Ludowi przypisane jest również prawo wyboru władz, co oznacza, że nie może on przekazać swojej suwerenności innemu podmiotowi ${ }^{35}$.

Wobec tego, co zostało wyżej napisane, można stwierdzić, iż w dokumentach soborowych demokracja jawi się jako akceptowana przez Kościół forma rządów. Jednakże jak słusznie podkreślają K. Grzybowski oraz B. Sobolewska, pod pojęciem demokracja może kryć się różnoraka treść. Jeśli chodzi o ramy funkcjonowania państwa i zakres praw jednostki, może istnieć demokracja „totalitarna” albo „wolnościowa”. Natomiast biorąc pod uwagę ustrój społeczno-gospodarczy, mówi się o demokracji opartej na własności społecznej lub też na własności prywatnej. Kościół, zdaniem K. Grzybowskiego i B. Sobolewskiej, przyjął regułę „równoważenia się". Nie opowiedziano się bowiem ani za nieograniczoną wolnością, ani za nieograniczonym poddaniem się jednostki państwu w sferze politycznej. Kościół nie ustosunkował się pozytywnie również do dominacji nieograniczonej własności prywatnej, a także do monopolu dla własności społecznej w gospodarce ${ }^{36}$. Zgodnie z treścią Gaudium et spes, modelem najbardziej odpowiednim dla współczesnego świata jest model jakiegoś ustroju mieszanego.

Jak słusznie zauważają K. Grzybowski i B. Sobolewska, zasadniczym pojęciem dla tego modelu jest, zawarta przez Jana XXIII w encyklice $P a$ cem $i$ terris, idea „dobra wspólnego" ${ }^{37}$. W Pacem in terris czytamy, że „wszyscy ludzie oraz wszelkie pośrednie zrzeszenia ludzkie powinny współdziałać w realizacji dobra ogółu, wynika z tego przede wszystkim, że mają one uzgadniać własne korzyści z potrzebami innych oraz obracać swoje dobra i usługi na cele wyznaczone przez władze państwowe zgod-

34 Cyt. za K. Grzybowski, B. Sobolewska, Doktryna polityczna i społeczna papiestwa (1789-1968), Warszawa 1971, s. 188.

${ }^{35}$ Konstytucja duszpasterska o Kościele w świecie współczesnym (Gaudium et spes), w: Dokumenty, w: K. Grzybowski, B. Sobolewska, Doktryna polityczna i społeczna papiestwa (1789-1968), Warszawa 1971, s. 488-487.

36 K. Grzybowski, B. Sobolewska, Doktryna polityczna i społeczna papiestwa (1789-1968), Warszawa 1971, s. 189.

37 K. Grzybowski i B. Sobolewska wskazują na inne niż dotychczas ujęcie zasady „dobra wspólnego”. W odróżnieniu od swoich poprzedników, Jan XXIII postrzega dobro wspólne jako wartość „dynamiczną” (ibidem). 
nie z nakazami sprawiedliwości i zasadami stanowienia praw. Ci zaś, którzy sprawują władzę w państwie, winni wydawać takie akty prawne, które nie tylko są doskonałe same w sobie, lecz ponadto, bądź bezpośrednio mają dobro państwa na celu, bądź mogą do niego prowadzić”38. Zasadę „wspólnego dobra” Jan XXIII pojmuje „dynamicznie”. Zdaniem K. Grzybowskiego oraz B. Sobolewskiej fakt ten może oznaczać, iż Kościół nie preferuje ,jakiegoś idealnego, ponadczasowego i niezmiennego modelu ustrojowego, lecz właśnie zmienność w ramach ogólnych zasad"39.

W Pacem in terris odniesiono się wielokrotnie do wygłoszonego w Wigilię Bożego Narodzenia 1944 roku orędzia Piusa XII. W myśl tej encykliki, w przypadku, gdy „sprawujący władzę w państwie wydają prawa, względnie nakazują coś wbrew temu porządkowi ${ }^{40}$, a tym samym wbrew woli Bożej, to ani ustanowione w ten sposób prawa, ani udzielone kompetencje nie zobowiązują obywateli" ${ }^{41}$. Następnie cytując fragment Dziejów Apostolskich przypomniano, o tym, że „bardziej trzeba słuchać Boga niż ludzi”" ${ }^{\text {,2 }}$ Mamy więc tu nieśmiały powrót do średniowiecznej koncepcji o prawie oporu wobec władzy, nawet formalnie legalnej, jeżeli w treści stanowionego przez nią prawa, a także innych działań jest ona tyrańska. Warto powtórzyć za K. Grzybowskim i B. Sobolewską, iż w odniesieniu do nauczania Jana XXIII oraz Gaudium et spes oraz encykliki Populorum progressio pogląd ten można uważać za skierowany przeciw dyktaturom faszystowskim, komunistycznym oraz skrajnemu kapitalizmowi ${ }^{43}$. W konstytucji napisano bowiem, że „nieludzką jest rzeczą, gdy władza polityczna przybiera formy totalitarne lub dyktatorskie, które naruszają prawa jednostek lub zrzeszeń społecznych"44.

38 Jan XXIII, Pacem in terris, w: Dokumenty, w: K. Grzybowski, B. Sobolewska, Doktryna polityczna i społeczna papiestwa (1789-1968), Warszawa 1971, s. 391.

39 K. Grzybowski, B. Sobolewska, Doktryna polityczna i spoleczna papiestwa (1789-1968), Warszawa 1971, s. 189.

40 Chodzi tu o prządek zgodny ze nauczaniem Kościoła. Przypis własny, nie jest integralną częścią cytatu.

${ }^{41}$ Jan XXIII, Pacem in terris, w: Dokumenty, w: K. Grzybowski, B. Sobolewska, Doktryna polityczna i społeczna papiestwa (1789-1968), Warszawa 1971, s. 391.

42 Dz. Ap. 5, 29.

43 K. Grzybowski, B. Sobolewska, Doktryna polityczna i społeczna papiestwa (1789-1968), Warszawa 1971, s. 189.

44 Konstytucja duszpasterska o Kościele w świecie współczesnym (Gaudium et spes), w: Dokumenty, w: K. Grzybowski, B. Sobolewska, Doktryna polityczna i społeczna papiestwa (1789-1968), Warszawa 1971, s. 488-488. 
Jak wcześniej powiedziano, ojcowie soborowi za fundamentalną zasadę w relacjach pomiędzy Kościołem a państwem uznali wolność Kościoła. Trafnie formułuje jej genezę P. Borecki - „Postrzegana jako wspólnotowy aspekt zakorzenionej w ludzkiej godności wolności w sprawach religijnych, została odniesiona do wszystkich związków wyznaniowych w całokształcie ich działania"45. Do wolności w sensie pozytywnym zaliczono: rządzenie się wspólnot wyznaniowych własnym, stanowionym przez nie prawem; wolność publicznego kultu; swobodę pomocy wiernym w uczestniczeniu w życiu religijnym; wspierania ich nauczaniem; a także rozwoju instytucji służących samorealizacji wyznawców zgodnie z zasadami religijnymi $^{46}$.

W Gaudium et spes czytamy również, że „Kościół winien mieć zawsze wszędzie prawdziwą swobodę w głoszeniu wiary, w uczeniu swojej nauki społecznej, w spełnianiu nieskrępowanie wśród ludzi swego obowiązku, a także w wydawaniu oceny moralnej nawet w kwestiach dotyczących spraw politycznych, kiedy domagają się tego podstawowe prawa osoby lub zbawienie dusz, stosując wszystkie i wyłącznie te środki, które zgodne są z Ewangelią i dobrem powszechnym według różnorodności czasu i wa-

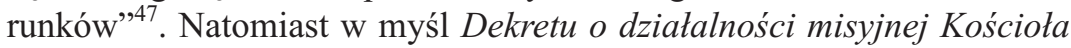
- Kościół „w żadnym wypadku nie chce się wtrącać w rządy ziemskiego państwa $^{48}$ ". Jest zatem w tym miejscu widoczna poważna sprzeczność, tym bardziej, że Kościół nie określił jasno, w jakich okolicznościach ma prawo ingerować w sprawy polityczne, a w jakich takiego prawa nie posiada. Kościół w sposób arbitralny stanowi prawo, którego płaszczyzna oddziaływania rozciagga się na sferę polityki. Poza tym, z uznania iż „Wspólnota polityczna i Kościół są w swoich dziedzinach od siebie niezależne i autonomiczne"49 jednoznacznie wynika, iż ewentualne zaangażowanie Kościoła w problemy wewnątrzpaństwowe powinno być

45 P. Borecki, Koncepcja relacji Kościoła i państwa w nauczaniu społecznym Jana Pawła II, „Przegląd Religioznawczy” 2005, nr 1, s. 38.

46 Ibidem, s. 38-39.

47 Konstytucja duszpasterska o Kościele $w$ świecie współczesnym (Gaudium et spes), w: Dokumenty, w: K. Grzybowski, B. Sobolewska, Doktryna polityczna i społeczna papiestwa (1789-1968), Warszawa 1971, s. 488-489.

48 Cyt. za P. Borecki, Koncepcja relacji Kościoła i państwa w nauczaniu społecznym Jana Pawła II, „Przegląd Religioznawczy” 2005, nr 1, s. 39.

49 Konstytucja duszpasterska o Kościele $w$ świecie współczesnym (Gaudium et spes), w: Dokumenty, w: K. Grzybowski, B. Sobolewska, Doktryna polityczna i społeczna papiestwa (1789-1968), Warszawa 1971, s. 488-489. 
zaakceptowane, zgodnie z ideą przewodnia demokratycznego państwa prawa, przez większość obywateli. W przeciwnym wypadku prawo stanowione przez Kościół nie powinno posiadać w obrębie danego kraju mocy prawnej. Ponadto, zgodnie z treścią Gaudium et spes istnieje konieczność „obecności” Kościoła katolickiego na arenie międzynarodowej „aby pielęgnować i rozbudzać wspólnotę między ludźmi. Czyni to zarówno przez swoje instytucje publiczne, jak i przez pełne i szczere zespolenie wysiłków wszystkich chrześcijan, czerpiące swe natchnienie z samego pragnienia służenia ludzkości" ${ }^{\text {, }}$.

Niejasne wydaje się również najnowsze stanowisko Kościoła w kwestii definiowania demokracji. Jan Paweł II dążył do uszczegółowienia doktryny soborowej w sferze relacji państwo-Kościól, a jednocześnie wniósł do niej nowe elementy. W wypowiedziach papieża szczególne miejsce zajmuje problematyka praw i wolności człowieka zarówno w aspekcie jednostkowym, jak i wspólnotowym. Jan Paweł II wielokrotnie podkreślał, iż podstawowym zadaniem Kościoła jest obrona praw każdego człowieka i całej ludzkiej społeczności (wynikających z natury ludzkiej i naturalnego prawa). Jak pisze P. Borecki, ich poszanowanie było dla Karola Wojtyły podstawowym „kryterium odniesień Kościoła do współczesnych państw”. W encyklice Evangelium vitae papież pisze: „Nie [...] może istnieć prawdziwa demokracja, jeśli nie uznaje się godności każdego człowieka i szanuje jego praw" "51. Zgodnie z nauczaniem Jana Pawła II, mające źródło w nienaruszalnej godności ludzkiej prawa nie mogą w sposób nieograniczony być przedmiotem demokratycznych procedur.

W swojej ostatniej książce Pamięć i tożsamość papież pisze, iż trzy formy sprawowania rządów: monarchiczna, arystokratyczna oraz demokratyczna „,były urzeczywistniane w dziejach poszczególnych społeczeństw i w dalszym ciągu są urzeczywistniane, z tym że tendencja współczesna zdecydowanie zmierza ku ustrojowi demokratycznemu, jako najbardziej odpowiadającemu rozumniej i społecznej naturze człowieka, a w konsekwencji wymogom sprawiedliwości społecznej. Trudno bowiem nie przyjać, że jeżeli społeczeństwo składa się z ludzi, a człowiek jest istotą społeczną, to jest konieczne dopuszczenie każdego do uczestnictwa -

50 Ibidem, s. 498.

51 P. Borecki, Koncepcja relacji Kościoła i państwa w nauczaniu społecznym Jana Pawta II, „Przegląd Religioznawczy” 2005, nr 1, s. 41. 
choćby pośredniego we władzy" ${ }^{\text {"52 }}$. Pogląd Jana Pawła II na problem demokracji nie jest wolny od argumentów krytycznych. W encyklice Centesimus annus papież podkreślił, że demokracja to system, który „,zapewnia udział obywateli w decyzjach politycznych i rządzonym gwarantuje możliwość wyboru oraz kontrolowania własnych rządów”. Dodał jednakże, że istnieje niebezpieczeństwo wykrzywienia jej w stronę dyktatury ,wąskich grup kierowniczych, które dla własnych korzyści albo celów ideologicznych przywłaszczają sobie władzę w Państwie"53.

Ponadto, Jan Paweł II stwierdził, iż „Autentyczna demokracja możliwa jest tylko w państwie prawnym i w oparciu o poprawną koncepcję osoby ludzkiej” ${ }^{, 5}$. Państwo prawa ma realizować postulat każdej demokracji - budowania społeczeństwa wolnych obywateli razem wytrwale dążących do osiagnięcia wspólnego dobra. Papież przypomina, że to legalnie wybrany parlament zadecydował o powołaniu do władzy Hitlera. W związku z tym, Karol Wojtyła pisze: ,prawo stanowione przez człowieka ma swoje granice, których nie może przekraczać" ${ }^{55}$. Zrealizowanie idei demokracji wymaga ogromnej pracy. Konieczna jest „promocja zarówno poszczególnych osób, przez wychowanie i formację w duchu prawdziwych ideałów, jak i «podmiotowości» społeczeństwa, przez tworzenie struktur uczestnictwa oraz współodpowiedzialności" ${ }^{15}$.

Papież akceptuje demokrację, ale tylko zbudowaną w oparciu o wartości chrześcijańskie, takie jak prawda, wolność i dobro: „Historia uczy, że demokracja bez wartości łatwo przemienia się w jawny lub zakamuflowany totalitaryzm,57. W myśl nauczania Jana Pawła II, jeżeli „ostateczna prawda" nie stanowi dla działalności politycznej drogowskazu, to może dojść do instrumentalizacji ,idei i przekonań dla celów, jakie stawia sobie władza”. Z uwagi na bolesne doświadczenia ubiegłego stulecia, należy sądzić, iż Jan Paweł II słusznie obawiał się o losy współczesnych systemów demokratycznych.

52 Jan Paweł II, Pamięć i tożsamość. Rozmowy na przełomie tysiqcleci, Kraków 2005, s. 134.

53 Cyt. za O. J. Mazur, Politologia chrześcijańska, Częstochowa 2001, s. 85.

54 Ibidem.

55 Jan Paweł II, Pamięć i tożsamość. Rozmowy na przełomie tysiącleci, Kraków 2005 , s. 139.

${ }^{56}$ Cyt. za O. J. Mazur, Politologia chrześcijańska, Częstochowa 2001, s. 85.

57 Ibidem, s. 86. 
Na przestrzenni dziejów Kościoła dokonała się istotna zmiana w ocenie demokracji: od całkowitego jej potępienia do pozornego uznania. Watykan, bowiem popiera tylko demokrację zbudowaną w oparciu o wartości chrześcijańskie. Podmiotem ustanawiającym te zasady ma być instytucja Kościoła. Sobór powtórzył za Janem XXIII, że władza publiczna nie może działać wbrew porządkowi ustanowionemu przez Boga. Tym samym uprawnienia władzy państwowej w tym przedmiocie zostały podporządkowane dyrektywom Kościoła katolickiego. Można więc przypuszczać, że proponowany przez Kościół ustrój to swoista modyfikacja feudalizmu. Należy uznać, że dla wolności pojmowanej jako wolność wyboru, wyrażonej w udziale jednostki we władzy, a tym samym w stanowionym prawie, nadal w doktrynie Kościoła katolickiego nie ma miejsca.

\section{Summary}

Throughout the history of the Church a profound change in the assessment of democracy has taken place, from utter condemnation to apparent recognition. The Vatican only supports democracy which is based on Christian values. The institution of the Church is to be the authority to establish these values. Following John XXIII, the Vatican Council repeated that public authority could not act against the order settled by God. Thus the power of state authorities in this respect has been subjected to the directives of the Catholic Church. One can assume then that the political system proposed by the Church is a particular modification of feudalism. It should be ascertained that freedom - meaning the freedom of choice - expressed by individual participation in government and, consequently, in the enacted law, remains absent from the doctrine of the Catholic Church. 